\title{
Differences in the degree of nutrition and body composition of boys and girls of pubertal age
}

\author{
Elvira Nikšić ${ }^{1 \mathrm{ABDE}}$, Marko Joksimović ${ }^{\mathrm{ABCDE}}$, Edin Beganovići ${ }^{1 \mathrm{ABD}}$, Novica Gardaševićc ${ }^{3 \mathrm{ABCDE}}$ \\ ${ }^{1}$ University of Sarajevo, Bosnia and Herzegovina \\ ${ }^{2}$ National Football Club, Podgorica, Montenegro \\ ${ }^{3}$ Elementary School Dobrislav Đ. Perunović, Nikšić, Montenegro
}

Authors' Contribution: A - Study design; B - Data collection; C - Statistical analysis; D - Manuscript Preparation; E - Funds Collection.

\begin{tabular}{|c|c|}
\hline \multicolumn{2}{|l|}{ Abstract } \\
\hline Purpose: & $\begin{array}{l}\text { The nutritional status of children can be assessed on the basis of clinical examination, laboratory } \\
\text { procedures and anthropometric measurements. Height and body weight are most often used to } \\
\text { determine nutrition. Children and adolescents who are at risk of being overweight often also become } \\
\text { obese adults. }\end{array}$ \\
\hline Material: & $\begin{array}{l}\text { The research was conducted on a sample of } 136 \text { students ( } 67 \text { boys and } 69 \text { girls), with an average age of } \\
11.56 \text { years. The aim of the study was to determine the degree and differences in the degree of nutrition } \\
\text { and body composition in boys and girls of pubertal age. }\end{array}$ \\
\hline Results: & $\begin{array}{l}\text { Based on the obtained results, T-test for small independent samples, it was determined that there are } \\
\text { no statistically significant differences between boys and girls, both in the degree of nutrition and body } \\
\text { composition, estimated by } 10 \text { variables using bioelectric impedance InBody } 720 \text {. Also, it was found that } \\
19.70 \% \text { of boys are obese, as well as } 17.40 \% \text { of girls. Cumulatively with the percentage of malnourished } \\
\text { respondents, a total of } 61.50 \% \text { of boys were not normally fed, as were } 37.70 \% \text { of girls. The obtained results } \\
\text { indicate the need for a more extensive review of the analysed segments and a significantly larger sample } \\
\text { of respondents, in order to act preventively in the fight against obesity, as the leading epidemiological } \\
\text { health problem of today. }\end{array}$ \\
\hline Conclusions: & $\begin{array}{l}\text { It is obvious that physical activity based on physical education classes is not sufficient or is not sufficiently } \\
\text { represented to meet the challenges of the modern way of life of children. }\end{array}$ \\
\hline ( & 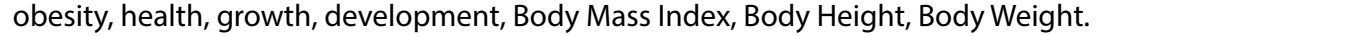 \\
\hline
\end{tabular}

\section{Introduction}

Monitoring the nutritional status is a very useful activity because it indicates the adequacy of the process of growth and development of children, helps to understand the current, and can also serve as a prognostic factor for their future health. The nutritional status of children can be assessed on the basis of clinical examination, laboratory procedures and anthropometric measurements. Height and body weight are most often used to determine nutrition. Children and adolescents who are at risk of being overweight often also become obese adults. Numerous characteristics of parents, including their education and income, influence the formation of the child's eating and living habits, and a particularly large role is attributed to the mother [1]. Small bodies need a quality diet to "survive" the school day, and the child's brain is hungrier than the body, it needs oxygen, energy, key nutrients, especially iron $(\mathrm{Fe})$, magnesium $(\mathrm{Mg})$ and $\mathrm{B}$ vitamin complex. If these needs are not met, children will have difficulty learning, remembering and maintaining concentration [2]. Proper nutrition of children should satisfy the body's need for daily energy intake and a sufficient amount of nutrients and protective substances that are necessary to maintain the physiological functions

\footnotetext{
๑) Elvira Nikšić, Marko Joksimović, Edin Beganović, Novica Gardašević, 2021

doi:10.15561/26649837.2021.0106
}

of the body and health. In addition to inadequate nutrition, physical activity also plays a significant role in the level of body fat in the body. There is less and less space to play outside. Today, children play in houses, indoors, and these are the most common games on the computer, mobile phone and play station. Lack of play leads to a decrease in the use of natural forms of movement, which affects the reduced level of motor skills, and thus to lower calorie consumption [3]. The most significant disorder is obesity, which is increasingly prevalent in adolescent children. Ten years ago, statistical data showed that $10.5 \%$ of children in Croatia have increased body weight, and $3.8 \%$ of them are obese. The latest data from the Croatian Institute of Public Health (HZJZ) indicate that $26.4 \%$ of school-age children are overweight, while $11.2 \%$ are obese. Croatia is in a worrying FIFTH place in Europe in terms of the number of overweight children [4]. According to the World Health Organization [5], childhood obesity is one of the biggest global public health challenges of the $21 \mathrm{st}$ century, and it is estimated that in the last 40 years, the number of obese school-age children and adolescents has increased tenfold. The etiology of childhood obesity is very complex, but dietary and life habits play a very important role [6]. Baranowski, Taveras [7] point out that the current approach to childhood obesity has not yielded the expected results and that preventive measures need to be strengthened activities at all levels, starting with 
parents. In the study conducted on the ITOF criterion, the majority of children, 165 and $65.74 \%$, respectively, were normally fed, as many as $21.51 \%$ were malnourished, while children with increased body weight were $7.97 \%$ and $4.78 \%$ obese, without significant statistical difference according to the sex of children [8]. Therefore, the diagnosis of the state of body composition is often the subject of research based on which a realistic insight into the current state of the defined population and possible negative or positive trends of growth and development over a period of time [9]. Based on all the above, the aim of this study is to determine the degree and differences in the degree of nutrition and body composition in boys and girls of pubertal age.

\section{Material and methods}

\section{Participants}

The study included a sample of 136 students divided into two subsamples: 67 boys with average values of Body Height $(\mathrm{BH}) 156.44 \pm 10.37 \mathrm{~cm}$, Body Weight (BW) $50.25 \pm 11.57$ and Body Mass Index (BMI) 20.32 $\pm 3.22 \mathrm{~kg} / \mathrm{m}^{2}$, chronological age $11.63 \pm 0.95$ years and 69 girls average BH $156.31 \pm 8.09 \mathrm{~cm}, \mathrm{BW} 49.07 \pm 12.09$ $\mathrm{kg}$ and BMI $20.1 \pm 3.66 \mathrm{~kg} / \mathrm{m}^{2}$, chronological age 11.55 \pm 0.90 years.

The sample of variables

The sample of variables used in the study represents a set of 13 variables. To assess the anthropometric characteristics, 3 variables were taken: body height $(\mathrm{BH})$, body weight (BW) and body mass index (BMI). To assess body composition, 10 variables were identified:

- Total Body Water, L (TBW);

- $\quad$ Proteins, kg; Minerals, kg;

- $\quad$ Body Fat Mass, kg (BFM);

- $\quad$ Soft Lean Mass, \% (SLM);

- $\quad$ Ratio, \%; BFM / SLM;

- $\quad$ Fat Free Mass, kg (FFM);

- $\quad$ Skeletal Muscle Mass, kg (SMM);

- $\quad$ Minerals in the Bones, \% (MB);

- $\quad$ Percent Body Fat, \% (PBF).

Research Design

Anthropometric variables were measured according to standard procedures of the International Society for the Advancement of Kinanthropometry (ISAK) [10]. Based on the variables $\mathrm{BH}$ and $\mathrm{BW}, \mathrm{BMI}[\mathrm{BMI}=\mathrm{BH}(\mathrm{kg}) / \mathrm{BW}$ $(\mathrm{cm})^{2}$ ] was calculated. BMI values for both subsamples were classified into 4 nutritional levels, according to the recommendations of the Centers for Disease Control and Prevention, 2000 [11] Table 1.

Table 1. Categorization of nutrition based on percentiles

\begin{tabular}{lll}
\hline BMI & Percentile & Weight \\
\hline BMI $\geq$ & 95th percentile & Obesity \\
$\mathrm{BMI}=$ & 85-95th percentile & Overweight \\
$\mathrm{BMI}=$ & 5-85th percentile & Normal weight \\
$\mathrm{BMI} \leq$ & 5th percentile & Malnutrition \\
\hline
\end{tabular}

Body composition was measured with an InBody 720 scale [12]. The validity of determining the body composition with InBody720 scales on a sample of children has been positively evaluated in some previous studies $[13,14]$. The research was approved by the Ethics Commission of the Faculty of Education, University of Sarajevo [15]. All parents are informed in advance about the implementation of the research which explains the purpose and goal of the research. Therefore, the research was supported by all parents, with written consent.

\section{Statistical Analysis}

All data collected by the research were processed by descriptive and comparative statistics. From the space of descriptive statistics, the arithmetic means, and standard deviation were calculated for each variable, while the T-test for small independent samples was used to determine the differences. The statistical program for personal computers SPSS for Windows-version 20.0 was used for data processing.

\section{Results}

Table 2 presents the results of the T-test for small independent samples and the results of the basic parameters of descriptive statistics, arithmetic mean (Mean) and standard deviation (Std.Dev). Based on the obtained values, it was determined that there are no statistically significant differences between the respondents, i.e. that the variances are the same in all variables by groups. Insight into the results of the arithmetic mean for all variables, it can be confirmed that these are approximately the same values, with slight differences, which are not recognized by statistical processing and application of the t-test.

Table 2. Differences in the BMI between boys and girls Descriptive statistic, T-test

\begin{tabular}{|c|c|c|c|c|}
\hline Variables & Gender & $\begin{array}{l}\text { Mean } \pm \text { Std. } \\
\text { Dev. }\end{array}$ & $\begin{array}{l}\text { T-test } \\
\text { t-value }\end{array}$ & $\mathbf{P}$ \\
\hline \multirow{2}{*}{$\begin{array}{l}\text { Body Height } \\
(\mathrm{cm})\end{array}$} & $\sigma^{\lambda}$ & $156.44 \pm 11.57$ & \multirow{2}{*}{.083} & \multirow{2}{*}{.934} \\
\hline & $q$ & $156.31 \pm 8.09$ & & \\
\hline \multirow{2}{*}{$\begin{array}{l}\text { Body Weight } \\
\text { (kg) }\end{array}$} & $\hat{\sigma}$ & $50.25 \pm 11.57$ & \multirow{2}{*}{.579} & \multirow{2}{*}{.564} \\
\hline & $q$ & $49.07 \pm 12.09$ & & \\
\hline \multirow{2}{*}{$\begin{array}{l}\text { Body Mass } \\
\text { Index }\left(\mathrm{kg} / \mathrm{m}^{2}\right)\end{array}$} & $\hat{\sigma}$ & $20.32 \pm 3.22$ & \multirow{2}{*}{.757} & \multirow{2}{*}{.450} \\
\hline & q & $20.1 \pm 3.66$ & & \\
\hline
\end{tabular}

Table 3 shows the percentile values for the variable BMI, based on which it is possible to see the nutritional status of the subjects by gender and level of nutrition. A very high percentage of overweight and obese respondents is evident, especially among boys $(41.80 \%$ overweight and $19.70 \%$ obesity). The degree of obesity is approximately equal between boys and girls (19.7\% -17.4\%), while there is a significant difference between the degree of normal nutrition $(38.80 \%-60.90 \%)$. 
In Figure 1 and 2, the arithmetic means of the percentile values for BMI were positioned, in both sexes. In the boy sample, the average percentile value is 85 th percentile, which indicates that it is a subsample that is on the border between normal nutrition and malnutrition. A slightly milder picture of the nutritional status is found in girls, but with a very similar tendency towards the boundary between the degree of normal and excessive nutrition of the complete subsample.

Analysing the results, shown in Table 4, it is noticeable that there are some gender differences in the indicators of body composition between boys and girls of pubertal age. However, as these differences can only reflect random variations in the sample, their significance was examined using a t-test for small independent samples. Analysis of T-test results shows that there are no statistically significant differences in body composition between boys and girls, in any of the 10 variables.

\section{Discussion}

The results of this study found that there were no statistically significant differences between boys and girls, both in the level of total nutrition assessed by body mass index (BMI) and in the body composition determined by the bioelectrical impedance InBody 720 . Based on the frequency of percentile values, $19.70 \%$ of boys and $17.40 \%$ of girls were found to be obese. The results obtained in this study have significantly higher values compared to the results obtained on a sample of respondents aged $11 \pm 6$ years obtained by [16]. In this study, boys had average values: $\mathrm{BH}: 146.60 \mathrm{~cm}, \mathrm{BW}$ : $40.78 \mathrm{~kg}$ and BMI: $18.83 \mathrm{~kg} / \mathrm{m} 2$, while in girls the values were: $147.40 \mathrm{~cm}, 40.50 \mathrm{~kg}$ and $18.57 \mathrm{~kg} / \mathrm{m} 2$. The prevalence of obesity in the pediatric population has increased threefold in the most developed countries over the past 20 years, and it is thought that such a condition will have a number of negative health consequences in the future [17]. The results showed that a large percentage of boys were overfed $(41.80 \%)$, which together with boys who are obese $(19.70 \%)$ amounts to an alarming $61.50 \%$ of respondents who do not have a normal level of nutrition. In girls, the condition is somewhat different, and the results show that about $37.70 \%$ do not have normal nutrition. However, based on Figure 2, it can be concluded that girls are mostly fed to a degree that is on the verge of normal nutrition, i.e. close to malnutrition, so the statistical procedure and the application of the T-test did not reveal differences at a statistically significant level between the sexes. Increased nutrition on the side of boys compared to girls has been found in previous researches. Jakšić et al. [18] stating the results: „Directorate for employment, labour and social affairs, data from 2014, the highest prevalence of OWOb (overweight/obesity) was recorded in Greece (44\% of boys and 38\% of girls) followed by Italy (36\% vs. 34\%), New Zealand (34\% vs. $34 \%$ ), USA ( $30 \%$ vs. $30 \%$ ), while the lowest prevalence was recorded in Indonesia (11\% vs.8\%). Differences between prevalence of $\mathrm{OWOb}$ in favor of boys were found in China (24\%vs. 16\%), Hungary (28\%vs.23\%), Poland (17\% vs. $11 \%)$, whereas differences in favor of girls are present in South Africa (29\% vs. $11 \%$ ) and UK (26\% vs. $22 \%)$." The results of the research showed that apart from the fact that there is no difference in the level of nutrition of the respondents, there is also no difference in their body composition. Accordingly, it can be stated that these are respondents who have approximately the same lifestyle when it comes to nutrition, as well as physical activity. High values of free fats expressed in kilograms in girls and boys (37.99 vs 36.13 ), as well as the results of PBF (23.74 vs 24.68), and according to the percentile values of the level of nutrition of the subjects ( 85 th vs 78 th), it can be concluded that this is a sample of subjects whose lifestyle has no balance between diet, i.e. calorie intake and their consumption by physical activity. Obesity as a health problem in childhood has multiple causes, so in its solution it is necessary to apply a broad therapeutic approach that requires the participation of patients, family and environment. Therefore, nutrition depends on the relationship between energy production and its consumption in the human body [19]. Puberty is a succession of anatomical and physiological changes in early adolescence that mark the transition period from sexually immature to fully mature and is characterized by the development of reproductive functions, changes in body size, composition and function in response to sex hormones [20]. If in this period intensive growth

Table 3. Nutritional status and percentiles boys and girls

\begin{tabular}{lllllll}
\hline & Boys & & \multicolumn{3}{c}{ Girls } \\
Nutritional status & $\mathbf{n}$ & Percentiles & $\%$ & $\mathbf{n}$ & Percentiles & $\%$ \\
\hline Obesity & 13 & $\geq 95$ & 19.70 & 12 & $\geq 95$ & 17.40 \\
Overweight & 28 & $85-95$ & 41.80 & 14 & $85-95$ & 20.30 \\
Normal weight & 26 & $5-85$ & 38.80 & 42 & $5-85$ & 60.90 \\
Malnutrition & 0 & $<5$ & 0.00 & 1 & $<5$ & 1.40 \\
Total: & 67 & & 100.0 & 69 & & 100.0 \\
\hline
\end{tabular}




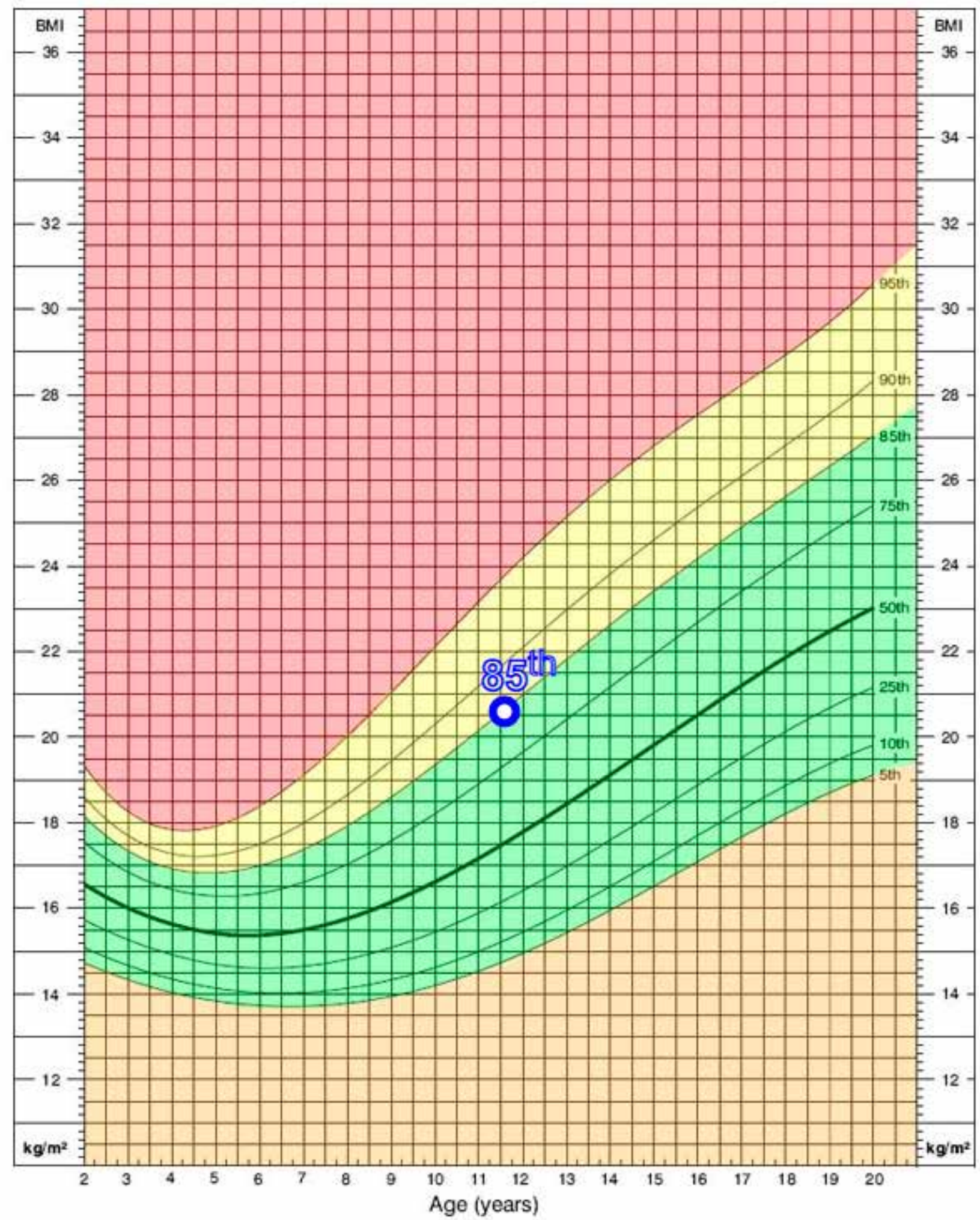

Figure 1. Percentile values of boys

and development are not based on healthy habits, the risk of developing various diseases, both in youth and in adulthood, is inevitable. In our country, as in the region, every third child spends three to five hours a day in front of a computer or TV, which significantly affects weight gain [21]. Kosti, Panagiotakos [22] point to the need to take urgent measures to combat obesity that has reached epidemiological proportions, where otherwise 1.3 million new cases of obese children can be expected worldwide. Đurković [23] points out that obesity, in addition to affecting a person's health status, also affects work productivity, as well as financial expenditures for the treatment of overweight and obese people. It is necessary to keep in mind that obesity, in both boys and girls, causes 


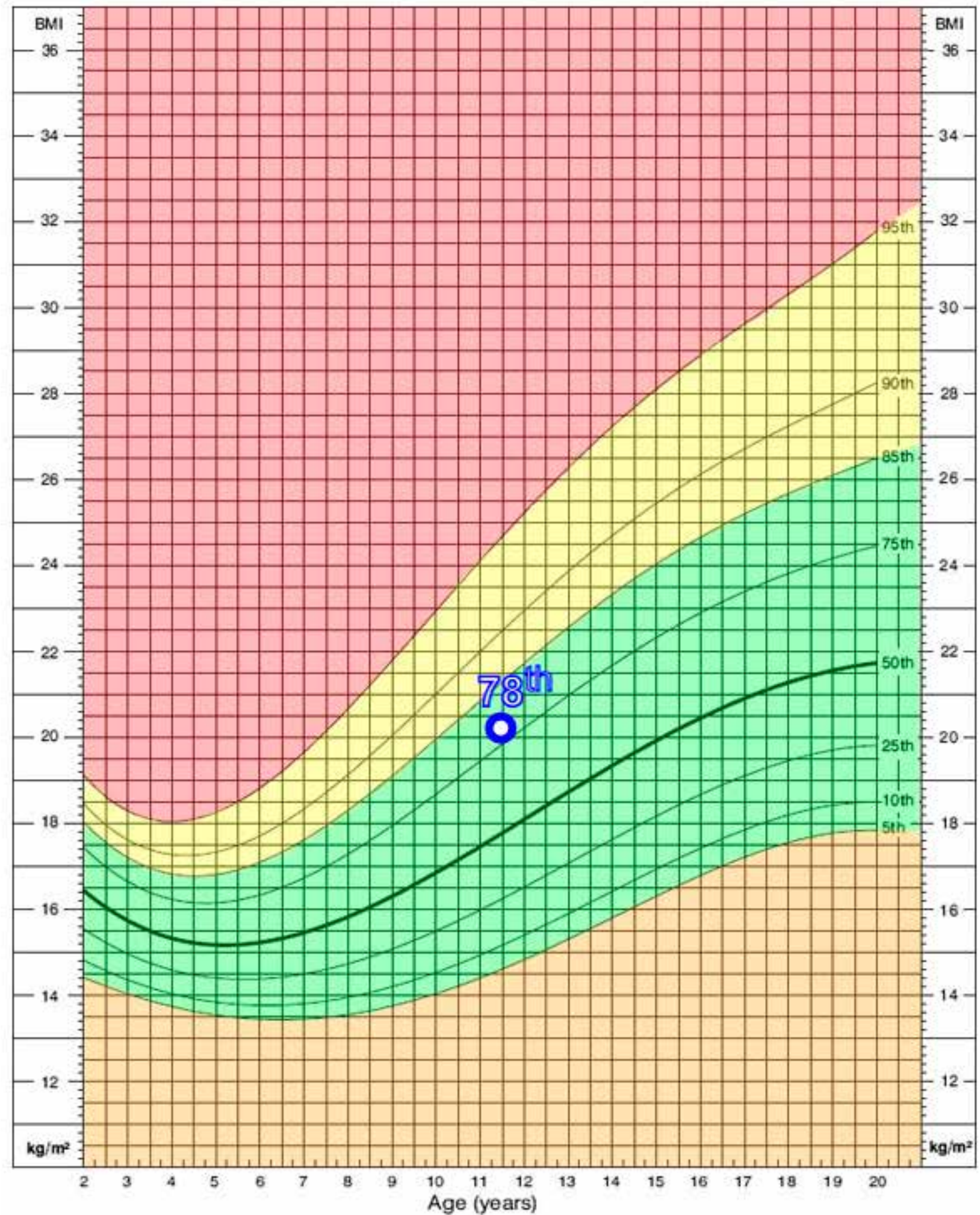

Figure 2. Percentile values of girls

dissatisfaction with their own appearance, which can cause various psychological processes in children, such as depression, withdrawal, non-fulfilment of their own potentials and others.

\section{Conclusion}

Obesity, as a health problem of the modern way of life, has gained epidemiological proportions around the world. It is obvious that this wave of epidemics is widely present in our country and in our immediate vicinity. Based on data indicating that $61.5 \%$ of male respondents and $37.70 \%$ of female respondents do not have normal nutrition, it can be concluded that our respondents are largely in the range of obesity and overeating with respondents from most developed countries, where obesity is the leading epidemiological health problem. 
Table 4. Differences in the body composition between boys and girls - Descriptive statistic, T-test

\begin{tabular}{|c|c|c|c|c|}
\hline \multirow{2}{*}{ Variables } & \multirow{2}{*}{ Gender } & \multirow{2}{*}{ Mean \pm Std.Dev. } & \multicolumn{2}{|l|}{ T-test } \\
\hline & & & $t$-value & $\mathbf{P}$ \\
\hline \multirow{3}{*}{ TBW } & $\hat{0}$ & $27.86 \pm 6.47$ & \multirow{3}{*}{1.289} & \multirow{3}{*}{0.20} \\
\hline & & & & \\
\hline & q & $26.60 \pm 4.8$ & & \\
\hline \multirow{3}{*}{ Proteins } & $\hat{0}$ & $7.47 \pm 1.75$ & \multirow{3}{*}{1.432} & \multirow{3}{*}{0.15} \\
\hline & & & & \\
\hline & q & $7.09 \pm 1.30$ & & \\
\hline \multirow{3}{*}{ Minerals } & 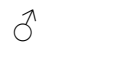 & $2.67 \pm 0.61$ & \multirow{3}{*}{0.979} & \multirow{3}{*}{0.32} \\
\hline & & & & \\
\hline & q & $2.57 \pm 0.49$ & & \\
\hline \multirow{3}{*}{ BFM } & $\hat{0}$ & $12.25 \pm 6.72$ & \multirow{3}{*}{-0.467} & \multirow{3}{*}{0.64} \\
\hline & & & & \\
\hline & q & $12.79 \pm 6.78$ & & \\
\hline \multirow{3}{*}{ SLM } & $\hat{0}$ & $35.79 \pm 8.31$ & \multirow{3}{*}{1.314} & \multirow{3}{*}{0.19} \\
\hline & & & & \\
\hline & q & $34.14 \pm 6.19$ & & \\
\hline \multirow{3}{*}{ Ratio BFM/SLM } & $\hat{0}$ & $0.35 \pm 0.19$ & \multirow{3}{*}{-0.364} & \multirow{3}{*}{0.71} \\
\hline & & & & \\
\hline & q & $0.36 \pm 0.15$ & & \\
\hline \multirow{3}{*}{ FFM } & $\hat{0}$ & $37.99 \pm 8.82$ & \multirow{3}{*}{1.391} & \multirow{3}{*}{0.16} \\
\hline & & & & \\
\hline & q & $36.13 \pm 6.65$ & & \\
\hline \multirow{3}{*}{ SMM } & $\hat{0}$ & $20.50 \pm 5.28$ & \multirow{3}{*}{1.364} & \multirow{3}{*}{0.17} \\
\hline & & & & \\
\hline & q & $19.40 \pm 3.94$ & & \\
\hline \multirow{3}{*}{$\mathrm{MB}$} & $\hat{0}$ & $2.20 \pm 0.51$ & \multirow{3}{*}{0.679} & \multirow{3}{*}{0.49} \\
\hline & & & & \\
\hline & q & $2.15 \pm 0.42$ & & \\
\hline & $\widehat{0}$ & $23.74 \pm 9.85$ & & \\
\hline PBF & & & -0.604 & 0.54 \\
\hline & q & $24.68 \pm 8.11$ & & \\
\hline
\end{tabular}

NOTE: Total Body Water, L; BFM - Body Fat Mass, kg; SLM - Soft Lean Mass, \%; FFM - Fat Free Mass, kg; SMM - Skeletal Muscle Mass, kg; MB - Minerals in the Bones, \%; PBF - Percent Body Fat, \%.

The obtained data, although conducted on a small sample, indicate the need for urgent consideration of things when it comes to this health problem and the inclusion of all segments of society in solving the problem. It is obvious that physical exercise, represented through the teaching of physical education in primary school, cannot respond and act preventively on the challenges of the modern way of life of children.

\section{Conflict of interest}

Authors declare no conflict of interest 


\section{References}

1. Banjari I, Odobaša R. Poverty and extremes in nutritional status of children. 27th International Scientifics Conference on Economic and Social Development, Roma, 2018. P.537545.

2. Taljić I. Ishrana školske djece $i$ adolescenata [Nutrition of school children and adolescents]. Sarajevo: University of Sarajevo, Center for Interdisciplinary Studies; 2019. (In Serbian)

3. Nikšić E, Rašidagić F, Beganović E. Postural disorders in primary school students, their prevention and correction. Faculty of Educational Sciences, University of Sarajevo. 2019. (In Serbian).

4. Kolarić T, Nožinić D. Pretilost-loše navike ili stil života današnjice [Obesity - bad habits or the lifestyle of today]. [In Serbian]. Split: Croatian Spring Pediatric School; 2016. (In Serbian).

5. WOF/WHO, World Obesity Federation and World Health Organization: Taking Action on Childhood Obesity Report. World Health Organization; 2018.

6. Kumar MD, Kelly AS. Review of Childhood Obesity: From Epidemiology, Etiology, and Comorbidities to Clinical Assessment and Treatment. Mayo Clinical Proceedings, 2017; 92(2):251-265. https://doi.org/10.1016/j.mayocp.2016.09.017

7. Baranowski T, Taveras EM Childhood Obesity Prevention:Changin the focus. Chilehood Obesity, 2018; 14(1): 1-3. https://doi.org/10.1089/chi.2017.0303

8. Paić A. Utjecaj roditelja na stanje uhranjenosti te prehrambene $i$ životne navike djece starosti 7 godina [The influence of parents on the state of nutrition and eating and living habits of children aged 7 years]. [In Serbian]. Osijek: Specialist paper, Josip Juraj Strossmayer University of Osijek, Faculty of Food Technology; 2019. (In Serbian).

9. Dopsaj M, Milošević M, Vučković G, Blagojević M, Mudrić R. Dijagnostika stanja indeksa telesne mase studenata Policijske akademije [Diagnostics of the body mass index of students of the Police Academy. Sportska Medicina. 2005; 5(4): 180-191. (In Serbian).

10.Marfell-Jones M, Olds T, Stew A, Carter L. International Standards for Anthropometric Assessment. Australia: The International Society for the Advancement of Kinanthropometry; 2006. https://doi.org/10.4324/9780203970157

11.Kuczmarski R, Kuczmarski MF, Roche AF. 2000 CDC Growth Charts: Background for Clinical Application. Top Clin Nutr. 2002; 17(2): 15- 26. https://doi.org/10.1097/00008486-200203000-00006

12.Aandstad A, Holtberget K, Hageberg R, Holme I, Anderssen SA. Validity and reliability of bioelectrical impedance analysis and skinfold thickness in predicting body fat in military personnel. Military Medicine. 2014; 179(2): 208- 217. https://doi.org/10.7205/MILMED-D-12-00545
13.Lim JS, Hwang JS, Lee JA, Kim DH, Park KD, Jeong JS, et al. Cross-calibration of multi-frequency bioelectrical impedance analysis with eight-point tactile electrodes and dual-energy X-ray absorptiometry for assessment of body composition in healthy children aged 6-18 years. Pediatrics International, 2009;51:263-8. https://doi.org/10.1111/j.1442-200X.2008.02698.x

14.Tompuri TT, Lakka TA, Hakulinen M, Lindi V, Laaksonen DE, Kilpeläinen TO, et al. Assessment of body composition by dual-energy X-ray absorptiometry, bioimpedance analysis and anthropometrics in children: the Physical Activity and Nutrition in Children study. Clin Physiol Funct Imaging, 2015;35:21-33. https://doi.org/10.1111/cpf.12118

15.World Medical Association. World Medical Association Declaration of Helsinki Ethical Principles for Medical Research Involving Human Subjects. JAMA, 2013; 310 (20). https://doi.org/10.1001/jama.2013.281053

16.Mitrović N, Pelemiš M, Pelemiš V. Analiza uhranjenosti kod dečaka i devojčica mčađeg školskog uzrasta [Nutritional analysis in boys and girls of school age]. Bijeljinski medicinski časopis, 2014;1: 41-48. (In Serbian).

17.Ebbeling CB, Pawlak DB, Ludwig DS. Childhood obesity: public-health crisis, common sense

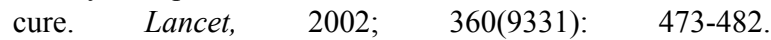
https://doi.org/10.1016/S0140-6736(02)09678-2

18.Jaksic M, Martinovic M, Belojevic G, Kavaric N, Asanin B, Samardzic M, et al. Prevalence of and contributing factors to overweight and obesity among the schoolchildren of Podgorica, Montenegro. Srp Arh Celok Lek, 2017;145:20-5. https://doi.org/10.2298/SARH151117003J

19.Đurašković R, Pantelić S, Nikolić M, Popović-Ilić T. Razlike u težinsko visinskim odnosima i uhranjenosti učenika starih 7 godine merenih 1988 i 2008. godine [Differences in weightheight ratios and nutrition of 7-year-old students measured in 1988 and 2008]. Glasnik antropološkog društva Srbije. 2008; 47: 181-191. (In Serbian).

20.Perroni F, Pintus A, Frandino M, Guidetti L, Baldari C. Relationship Among Repeated Sprint Ability, Chronological Age, and Puberty in Young Soccer Players. Journal of Strength and Conditioning Research, 2018; 32(2): 364-371. https://doi.org/10.1519/JSC.0000000000001799

21.Despotović M, Alekxopulos H, Despotović M, Ilić B. Stanje uhranjenosti dece predškolskog uzrasta [Nutritional status of preschool children]. Medicinski časopis, 2013; 47(2): 62-68. (In Serbian).

22.Kosti RI, Panagiotakos DB. The epidemic of obesity in children and adolescents in the world. Central European Journal of Public Health, 2006; 14(4): 151-159. https://doi.org/10.21101/cejph.a3398

23.Đurković M. Gojaznost kao politički i teorijski problem [Obesity as a political and theoretical problem]. Medicinski glasnik.,2012; 44(17): 32-49. (In Serbian). https://doi.org/10.5937/medgla1244032D 
Information about the authors:

Elvira Nikšić; (Corresponding author); https://orcid.org/0000-0002-1849-9693; elvira.beganovic1982@gmail.com; Faculty of Education Science, University of Sarajevo; 71000 Sarajevo, Bosnia and Herzegovina.

Marko Joksimović; http://orcid.org/0000-0003-4232-5033; nicifor007@outlook.com; Football Club Nacional, Ljajkovići bb 81000 Podgorica, Montenegro.

Edin Beganović; https://orcid.org/0000-0002-5190-6035; edinn.beganovic@hotmail.com; Faculty of Physical Education and Sport, University of Sarajevo, 71000 Sarajevo; Bosnia and Herzegovina.

Novica Gardašević; http://orcid.org/0000-0001-8358-7297; nowica@t-com.me; Primary school Dobrislav Đ. Perunović, 81400 Nikšić, Montenegro.

Cite this article as:

Nikšić E, Joksimović M, Beganović E, Gardašević N. Differences in the degree of nutrition and body composition of boys and girls of pubertal age. Pedagogy of Physical Culture and Sports, 2021;25(1):39-46.

https://doi.org/10.15561/26649837.2021.0106

This is an Open Access article distributed under the terms of the Creative Commons Attribution License, which permits unrestricted use, distribution, and reproduction in any medium, provided the original work is properly cited (http://creativecommons.org/licenses/by/4.0/deed.en).

Received: 10.06 .2020

Accepted: 15.07.2020; Published: 25.02.2021 